\title{
INDUSTRIAL DEVELOPMENT UNDER \\ INSTITUTIONAL FRAILTY: THE \\ DEVELOPMENT OF THE MEXICAN TEXTILE \\ INDUSTRY IN THE NINETEENTH CENTURY
}

\author{
AURORA GÓMEZ-GALVARRIATO \\ CIDE-MEXICO
}

\section{RESUMEN}

La industria textil moderna apareció en México tempranamente y creció de forma continua a lo largo del siglo xIx. Sin embargo, esto no se tradujo en un proceso de industrialización exitoso como resultado de altos costos de transporte y fragilidad institucional: concepto que incluye la incertidumbre, la debilidad y la fragmentación institucionales. La fragilidad institucional generó una política arancelaria capturada que otorgaba bajos niveles de protección efectiva a la industria, un mercado financiero atrasado que limitó los recursos disponibles al crecimiento industrial, y un crecimiento en los costos de transporte debido a las alcabalas. Los altos costos de transporte fragmentaron el mercado nacional y como resultado generaron una industria geográficamente dispersa.

\section{ABSTRACT}

Modern textile manufacture appeared early in Mexico and grew continuously through the $19^{\text {th }}$ century. Yet, it did not translate into a successful industrialization process as a result of naturally endowed high transportation costs and institutional frailty: a concept that encompasses institutional uncertainty, weakness and fragmentation. Institutional frailty generated a captured tariff policy that gave low effective protection to the industry, a backward financial market that limited resources available for industrial growth, and increased transportation costs through inter-state tariff barriers. High transportation costs fragmented the national market and as a result, the textile industry grew geographically dispersed. 


\section{INTRODUCTION *}

Mexico is generally considered a «newly industrialized country», yet industrial development did not come late to Mexico, rather, it appears to have taken a different less prosperous path. Mexico's first steps towards industrialization occurred earlier than in any other country outside of Europe and British North America, except Egypt ${ }^{1}$. Mexico's «industrialists», as they called themselves, established the first mechanized mills in the $1830 \mathrm{~s}$; around the same time that the Lowell mills were built, and only twenty years after the first mechanized mill was established in the United States. Brazil, the other precocious industrializer in Latin America, established its first mills in the 1840s. Yet, by 1853 it only had 8 mills with 4500 spindles $^{2}$ while ten years earlier Mexico's textile manufacture included 59 mills with more than 100,000 spindles ${ }^{3}$. In Japan, the government built that country's first modern cotton spinning mill in 1867, but it failed. The first successful private mills did not appear until a decade later ${ }^{4}$.

The Mexican textile industry grew in the 19th century and adopted new technologies of production. Mechanized factories that used water and steam power replaced animal powered artisanal shops. However, this precocious industrialization did not prosper. Mexico's textile industry fell behind those of North America and Europe early in the $19^{\text {th }}$ century, and by century's end it was even behind those of some «underdeveloped» nations. By 1890, Japan's textile industry had almost twice as many spindles than its Mexican counterpart, and by 1905 the Brazilian textile industry counted more spindles than Mexico's ${ }^{5}$. The Mexican textile industry did not become internationally competitive until the last decade of the 20th century. It thus appears that during the 19th century, Mexico missed the chance to join the group of nations that profited from early industrialization.

«Institutions are the rules of the game in a society, or more formally, are the humanly devised constraints that shape human interaction» ${ }^{6}$. This

* The author beneffited from comments on an earlier draft of this paper by John Coatsworth, Alberto Diaz, Nancy Koehn, Joy Langston, Carlos Marichal, Noel Maurer, Aldo Musacchio, John Womack and the anonymous referees from this journal. All errors are my own.

'Egypt had 400,000 spindles by 1834. Batou (1991), p. 185.

2 Stein (1957), p. 191.

3 Alamán (1843), Appendix, Table 5.

4 Clark (1914), p. 41

5 Takajusa, (1990), p. 94, Haber (1997), pp. 162-163.

6 North (1990), p. 3. 
paper explores the factors that inhibited a more prosperous industrial development: institutional frailty -cause and consequence of political instability - and high transportation costs. I define institutional frailty as an inefficient institutional framework «that favor activities that promote redistributive rather than productive activity, that create monopolies rather than competitive conditions, and that restrict opportunities rather than expand them ${ }^{7}$ that has two dimensions: institutional uncertainty and institutional weakness.

Institutional uncertainty is institutional frailty in terms of time: the rules of the game continually change, and thus, there does not exist a reliable set of expectations about which present courses of actions will be rewarded or punished in the future. It is a product of the lack of permanence of governments in power and the lack of continuity of policies. It produces a risky environment that considerably reduces the time-span individuals and organizations take into account to act.

Institutional weakness is institutional frailty in terms of strength and scope: the rules of the game are not enforced systematically and benefit in a discretionary matter powerful players. Weak rulers are unable to carry on policies from which society would gain at the cost of particular interest groups of which they are easy prey.

When institutional weakness takes place in a territorial dimension I call it institutional fragmentation. The rules of the game are not homogeneous throughout the nation. Weak governments are unable to set rules and policies over the whole national territory from which the country would benefit at the cost of regional interests. Institutional fragmentation, together with high transportation costs, cut the nation into several regional economies, drastically limiting the size of markets businessmen can count on.

Through this paper I will explore these concepts grounding them on concrete historical events. The purpose of this paper is to analyze the causes and the nature of Mexico's textile industry growth and retardation from 1839 to 1879 and particularly between 1843 and 1879 , a period for which little historical knowledge exists. It deals with the questions of why modern textile manufacturing appeared so early in Mexico, and why it continued growing in such an unpropitious economic environment. This paper argues that institutional frailty and high transportation costs not only limited textile industry's growth, but that the way in which Mexico's early textile entrepreneurs overcame the obstacles they faced shaped the industry's growth,

\footnotetext{
${ }^{7}$ North (1990), p. 9.
} 
making it structurally different from its counterparts in the industrialized world. Mexican textile industry grew geographically dispersed, a characteristic that by itself could hinder Mexico's long term industrialization process.

\section{THE ORIGINS OF THE MEXICAN TEXTILE INDUSTRY}

Four conditions explain Mexico's early industrial growth. First, its relatively large population provided the market necessary for industry to develop. Second, a tradition of artisan textile production generated political support for protectionist policies. Third, high transport costs that resulted from the concentration of population far from the sea together with hip land gave textile manufactures a «natural» protection from foreign trade. And fourth, between 1830 and 1840 the national government, under the influence of statesmen such as Lucas Alamán and industrialists such as Estevan de Antunano provided both tariff protection and means of finance through a development bank, the Banco de Avío.

In 1835 Estevan de Antuñano established La Constancia Mexicana, the first enduring mechanized textile mill to operate in Mexico ${ }^{8}$. The Banco de Avio ${ }^{9}$, a government owned development bank ran by Lucas Alamán, financed it. Lucas Alamán (1792-1853) became the Minister of Interior and Foreign Affair in 1830. In that year he organized the creation of a bank for the promotion of industrialization: the «Banco de Avio para Fomento de la Industria Nacional.» His goals were to promote a mechanized industry that could produce, at a price and quality equal to foreign competitors, not merely to protect the inefficient artisanal production of colonial times. It was clear to him that more than mere tariff protection would be necessary to promote industrialization. He wrote: «The purely prohibitive systems cannot by themselves make factories flourish; other elements are needed, such as an abundant population, capital, and adequate machinery» ${ }^{10}$. Alamán believed that by itself the «invisible hand» was not going to lead to industrialization ${ }^{11}$.

${ }^{8}$ Technically «La Aurora Yucateca» was built first, in 1833, by Pedro Sainz de Baranda. However, its small size and the lack of reports of it in the Ministerio de Fomento documents, have made it to be rarely mentioned when talking of Mexico's industrial development, as Keremitsis points out. Keremitsis (1973), p. 18. See Cline (1947), pp. 30-31.

${ }^{9}$ For an excellent study on the Banco de Avío see Potash (1983).

${ }^{10}$ Memoria de la secretaría de estado y del despacho de relaciones interiores y exteriores, 1830: 29-30, in Potash (1983), p. 42.

"Potash (1983), p. 29. 
He devised a plan by which the total prohibition of textile imports would be replaced by tariffs. One fifth of the total duties accrued would go to form the capital of the Banco de Avio until one million pesos had been accumulated. The bank would lend money at low interest rates to those who wished to establish modern factories.

Alamán's Banco de Avío was a clever way to get around the vicious circle in which Mexican textile production was trapped. Low profits led to low investment, while low investment led to low profits and the inability to compete with foreign manufacturers. Free trade would have lowered profits even more, and inhibited the possibility of national textile production, but protection without investment became a heavy burden on the consumer without any compensation in terms of economic development. The bank tried to square the circle by translating lower protection into capital for investment. While the bank was never able to accumulate the planned capital of one million pesos, it was able to finance industrial projects until 1840 , when the bank ceased to function as an industrial loan agency.

Despite the haphazard way the bank functioned in those unstable years, it carried out a machine-purchasing program. In 1830 it bought five cotton mills and two paper mills from New England tool manufacturers ${ }^{12}$. In addition to these special purchase programs, the most important activity of the bank was lending money to private entrepreneurs. The Board of Directors of the Banco de Avío evaluated the projects submitted by the entrepreneurs and assigned funds accordingly. From 1830 to 1840, the bank gave forty loans of which thirteen went to cotton textile factories, while the rest financed paper mills and iron foundries. Half of the cotton textile mills opened with Banco de Avío credit still operated in $1845^{13}$. Three of those mills, La Constancia Mexicana, Cocolapan, and Industrial Jalapeña, still functioned in $1893^{14}$. Viewed from this perspective, the impact of the Banco de Avío on Mexican industrialization seems important. The bank's role in the promotion of industry must not be exaggerated: of the fifty-nine companies Alamán lists, only six received a bank loan. Nevertheless, it is possible that the establishment of the first firms - which did receive loans from the bank- had a positive externality on the creation of the ones that came later, giving a clear signal of the government's com-

12 Potash (1983), p. 55.

13 Potash (1983), p. 124.

14 México, Dirección Nacional de Estadística (1894), «Cuadro Estadístico de la Industria Fabril de Hilados y Tejidos de Lana y Alodón en los Estados Uniodos Mexicanos formado en 1893». 
mitment to industrialization. Moreover these mills were on larger scale than the median throughout the period.

Estevan de Antunano (1792-1847), Mexico's major industrialist of the time, wrote numerous pamphlets to promote the policies he considered the most appropriate for the growth of the textile industry. De Antuñano pondered the possibility that some day «the mechanical arts» of Mexico would reach those of the «enlightened nations». He wrote:

It is not only possible, but [certain that ] our factories one day can become more productive for us than their factories [of the enlightened nations] are for them, since we will work at a lower cost than they do, because of the advantage that nature gives us in an immense and exuberant land with a benign climate (...) We are also farther from the disturbances that originate in Europe and that very often jeopardize the progress of their industry (...) but (...) we are still far from the day when all this comes true! (...) We still have to remove many obstacles, and a great perseverance to prove, to achieve the apogee of happiness I have imagined.. however, there is nothing impossible for men when the means are provided! ${ }^{15}$.

Antuñano's optimism about the future of Mexican industry was not totally unfounded. He envisioned for Mexico the economic development that actually took place in the United States. The abundance of natural resources, together with the protection that the Atlantic offered from European wars were certainly an asset for development in the Western Hemisphere. In 1837, when the territory that today is Texas, California, Nevada and New Mexico still belonged to Mexico, and when Mexico still remembered its past as the most prosperous Spanish colony, Antuñano's hopes were not illusory.

At that time Mexico had the biggest population in the Western Hemisphere, after the United States. In 1820 Mexico's population was of 6.5 million inhabitants, only two-thirds of that of the United States. Brazil had only 4.5 million, Perú and Colombia, a little more than one million inhabitants, and the rest of the countries even fewer ${ }^{16}$. For the textile industry, this meant a large market if protectionist policies were undertaken.

Antuñano called for government intervention to assist industry against those who:

... after having occupied their memory in learning the principles and precepts of political economy, reading foreign authors, these theories have impassioned them so much that they are not only persuaded that it is possible

is De Antuñano (1837), p. 21.

${ }^{16}$ Maddison (1995), pp. 106-112. 
to achieve a manufacturing economy in Mexico (...), but they believe that it can be obtained, without national laws that support the first steps of the industry: they expect that it will appear by itself, without more impulse than scarcity; and since unfortunately this is abundant in Mexico, they deduct from this fact its possibility ${ }^{17}$.

He was a perfect partner for Lucas Alamán in the promotion of industrial development, and the two frequently exchanged correspondence. When Alamán was in an important position he helped Antuñano. Meanwhile, Antuñano helped translate Alamán's policies into actual factories.

Alamán's industrial policy, as Bernecker has pointed out, required stable political conditions over a long run, established on a basis of well organized public finances, an effective system of tax collection, and a gradual transition to an era of steady economic growth ${ }^{18}$. Unfortunately, political instability, cause and consequence of a permanent disorder in public finances, made these requirements impossible to attain in Mexico during most of the 19th century ${ }^{19}$. In the 55 years between Independence and the Porfiriato, the presidency changed hands 75 times ${ }^{20}$. Political instability generated institutional frailty under which it was impossible for the government to carry on a cogent industrial policy.

Constant wars put the federal government in permanent fiscal deficits which it financed through indebtment with private money lenders (agiotistas) and the church. From the fiscal perspective 19 th century Mexico was more a loose confederation than a federal regime. Tax collection was basically in the hands of the states that took control of the Patronato Real de la Nueva España and charged indirect taxes through inter-state tariff barriers. The federal government had very few fiscal sources except some monopolies and foreign trade taxes. Given that Mexico City is far away from ports, its control over foreign trade taxes depended more of state governments than of the federal one ${ }^{21}$. This situation generated weak federal governments. State governments were run by regional caciques (war-lords), such as Santiago Vidaurri, whose commitment to the federation that depended on the party in power ${ }^{22}$.

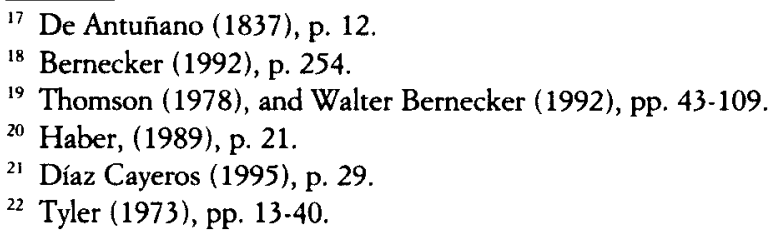




\section{THE MEXICAN COTTON TEXTILE INDUSTRY FROM 1836 TO 1843.}

The existence in the early $19^{\text {th }}$ century of a large artisan textile sector gave protectionism important political support ${ }^{23}$. Since 1829 , Mexican governments set tariff policies that protected textile manufactures. However, these protectionist measures were not part of an industrialization program. They can be understood as the accumulation of privileges granted to several interest groups, which many times contradicted each other. In 1836, representatives of the cotton-growing regions of Veracruz and Oaxaca successfully introduced a bill to ban the entry of raw cotton. The textile manufacturers did not oppose the bill, since domestic cotton production was sufficient to supply the small cotton textile industry. However, prohibition of raw cotton imports very soon produced terrible consequences. It made no economic sense to impose tariffs both on the products and on the inputs of the textile industry ${ }^{24}$. Three years later Antunano wrote several letters to President Santa Anna, explaining the problems that the ban on raw cotton caused the textile industry, trying to convince him to ease the prohibition ${ }^{25}$. Antuñano asked Santa Anna not to provide partial permits to import cotton, since this would give an unequal advantage to the certain factories in purchasing the necessary cotton ${ }^{26}$.

Santa Anna did not listen. In 1843 he gave an exclusive privilege to the Sres. Agüero González y Cia. to import 60,000 quintales. The company had to pay the government six pesos per quintal, or $\$ 360,000$ pesos in cash, within two months. Later in the same year a second permit was issued for 20,000 quintales under similar terms. Both permits were transferred to Cayetano Rubio, the owner of the Hércules mill, a merchant and a well known agiotista ${ }^{27}$. Santa Anna, political boss of a major cotton growing region, had too many commitments to cotton growers to relax their protection. Santa Anna himself may have been in the cotton business, thus having personal interests in the protection of raw cotton ${ }^{28}$. Govern-

${ }^{23}$ Thomson (1978) and Bernecker (1992), pp. $43-109$.

24 Illades (1989), p. 39.

${ }^{25}$ Letter from Antuñano to Santa Anna, Puebla, January 22, 1843; Illades (1989), p. 12.

${ }^{26}$ Letter from Antunano to Santa Anna, n.d.; in Illades (1989), p. 43.

${ }_{27}$ Decree of April 12, 1843, El Observador Judicial y de Legislación, pp. 366-67; Memoria que el Secretario de Hacienda.. presentó, 1844, p. 15 in Potash (1983), p. 142.

${ }^{28}$ Illades (1989), p. 41. 
ments may have given import permits to agiotistas as part of their negotiations in order to obtain further credits from them ${ }^{29}$.

Lucas Alamán, extensively criticized the prohibition of raw cotton imports in the 1843 Report of the Bureau of Industry. He wrote:

Contrary to what those interested in the monopoly of cotton have said, it is evident that the national cotton crop is not sufficient to provide the actual consumption for the established factories (...) From 1838 onwards cotton started to become scarce; and its price, which at that time was only 16 or 17 pesos per quintal, has increased to 40 pesos (...) There has never been a surplus from one year to another, and very far from this, the manufacturers have had to stop production, or to shorten daily production in order not to stop, waiting anxiously for the arrivals of the new crop ${ }^{30}$.

To Alamán, the cotton import permits that Santa Anna issued were better than nothing, since in their absence «the factories would have closed and the industry would have collapsed. «However», he wrote: «... that has been only a temporary remedy, and it is always of a dangerous nature, since a privilege is never more than a monopoly, and as the etymology of that word explains, it means richness for one and damage for all» ${ }^{31}$.

Raw cotton made up a very important percentage of production costs for textile mills. The data presented by Alamán suggests that cotton represented from fifty to sixty percent of production costs, while labor embodied about $30 \%$ of total costs. An estimation of a Cobb-Douglas production function using data for the industry in 1893 indicates a share of raw cotton in total costs of $72 \%{ }^{32}$.

${ }^{29}$ Bernecker (1992), pp. 226, 265.

${ }^{30}$ Alamán (1843), pp. 22-23.

${ }^{31}$ Alamán (1843), p. 24.

${ }^{32}$ A least squares estimation of a Cobb-Douglas production function using data for 89 factories operating in Mexico in 1893 gives the following results:

Dependent Variable is LQ

\begin{tabular}{|c|c|c|c|c|}
\hline Variable & Coefficient & Std. Error & T-Stat & 2-Tail Sig. \\
\hline C. & 0.8226 & 0.2295 & 3.5838 & 0.0007 \\
\hline . & 0.1167 & 0.0245 & 4.7558 & 0.0000 \\
\hline 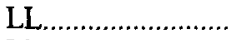 & 0.1796 & 0.0374 & 4.7978 & 0.0000 \\
\hline LM ........................ & 0.7241 & 0.0303 & 23.909 & 0.0000 \\
\hline LF.. & 0.0165 & 0.0215 & 0.7651 & 0.4471 \\
\hline
\end{tabular}

R-Squared: 0.984

Where LQ is the value of total production, LK is the value of capital, LL is the value of labor employed, LM is the value of cotton consumed and LF is the value of fuel consumed. 
Textile industrialists suffered special cotton import licenses arbitrarily granted by the government to a privileged few. They also had to withstand the granting of licenses for the importation of manufactured textiles. The precarious fiscal situation of the Mexican governments made their commitment to protect textile manufactures very vulnerable. In 1841 , for example, in order to finance the war against Texas, General Mariano Arista authorized the sale of special import licenses for textile manufactures. Guillermo Drusina and Cayetano Rubio purchased them over the harsh opposition of other textile producers ${ }^{33}$. Furthermore, textile manufacturers often complained of the prevalence of smuggling which further limited their markets ${ }^{34}$.

We can blame protectionism undertaken of Mexican governments in this period on institutional frailty. Their fiscal and military weakness and the concomitant constant change of government in power made it incapable of undertaking a trade policy focused on the promotion of industry. The weakness of national governments, both in terms of their capacity to implement policies and in terms of their lack of control of regional governments, made smuggling unavoidable. For governments in this period, short-term objectives always reigned over long-term ones. Given the precarious situation government faced, it was not in a situation to foster policies that would have increased government revenues in the long run, such as promoting industry and economic growth. They needed resources immediately in order to survive, and tried to obtain them at whatever cost was necessary.

Another problem the textile industry faced in this period was the backwardness of financial institutions. Apart from the Banco de Avio, which closed its doors in 1840, there was no institutional lending to industry until the 1880 s. Only after 1864 did a rudimentary banking system with specialized institutions and stable practices begin to develop in Mexico. By 1884 only eight banks were in operation in Mexico. Stephen Haber has studied the pernicious effect that the poor development of banking had on textile industry's growth and structure during the Porfiriato, when a financial system began to develop ${ }^{35}$. The limits it set on industrial growth before 1880 must have been even larger.

Choosing a Cobb Doublas function assumes a factor substitution elasticity equal to one. A trans-log functiton could be estimated to avoid this problem but there is insufficient data to do so.

${ }^{33}$ Walker (1991), p. 200.

34 Bernecker (1992), pp. 200, 215, and 221.

35 Haber (1997), pp. 161-171. 
Interest rates were exorbitantly high and fluctuated unpredictably, there were no banking institutions and there was no formal stock market. Industrialists had to rely on informal mechanisms of raising capital, in most cases based on kinship networks of credit. Studies of particular mills during this era tell of the serious difficulties businessmen faced obtaining credit, which frequently drove them to bankruptcy ${ }^{36}$. Successful entrepreneurs were those who undertook speculative activities as part of their businesses, such as money lending to the government. Agiotistas such as Cayetano Rubio, Pedro Berges de Zúñiga and Manuel Escandón became the major textile-mill owners by mid-nineteenth century. Their position as money lenders gave them two major assets other businessmen lacked: liquidity and a privileged position to negotiate concessions from the government, such as raw cotton import permits ${ }^{37}$. With these two aces in hand they were able to liquidate other competitors, and later to buy their mills at cheap prices, or simply obtain them when they defaulted their debts. We can understand this situation as one in which «the rules of the game» rewarded courses of action that were not those from which society benefited the most.

Mexico's financial system lagged behind not only those of developed countries, such as the United States, but also to those of other Latin American countries such as Brazil, Argentina, or Chile. Institutional frailty explains this relative backwardness. According to Carlos Marichal, the instability of Mexican financial markets and the difficulties in the development of modern capital markets during the greater part of the nineteenth century were mainly the result of the state's fiscal and credit policies ${ }^{38}$. Two basic preconditions for the development of capital markets were not present in nineteenth century Mexico: the stabilization and broadening of short-term money-markets and the creation of a relatively open, internal market for public securities ${ }^{39}$. These two conditions could not exist until the Mexican government's fiscal resources allowed it to pay its debts regularly. Political instability, prevalent through this period played against governments' fiscal health, and was also a result of it ${ }^{40}$.

In addition to the problems industrial expansion faced from the supply-side, the slow growth of domestic demand must also have placed

${ }_{36}$ Trujillo (1997), p. 254-255, and Illades (1989), pp. 44-46.

${ }^{37}$ Bernecker (1992), pp. 183-190.

${ }^{38}$ Marichal (1997), p. 119.

39 Marichal (1997), p. 119.

40 Further work needs to be undertaken in order to evaluate the impact of financial backwardness on the textile industry during the pre-Porfirian $19^{\text {th }}$ century. 
an important constraint on the growth of the textile industry. In the United States, demand changes accounted for more than half of the expansion of the industry between 1815 and 1833, in which sales increased by a $15.4 \%$ average rate per year. This was the result of rapid population growth, averaging $3 \%$ a year over the $1815-1840$ period, the rising income levels enjoyed by the growing population, and transportation improvements which further increased demand for textiles by reducing the difference between prices at the factory gate and those consumers actually faced ${ }^{41}$. In Mexico demand must have remained stagnant as population grew slowly between 1800 and 1845 at an average annual rate of $0.51 \%$, and income per capita decreased at the average annual rate of $0.6 \%$ during that period (See Table 1). No transportation improvements were carried on during these years.

TABLE 1

Population and Income

(average annual rate of growth)

\begin{tabular}{lcrr}
\hline & Population & $\begin{array}{c}\text { Income } \\
\text { per Capita }\end{array}$ & $\begin{array}{c}\text { Total } \\
\text { Income }\end{array}$ \\
\hline $1800-1845 \ldots \ldots \ldots$ & $0.51 \%$ & $-0.60 \%$ & $-0.10 \%$ \\
$1845-1860 \ldots \ldots \ldots$ & $0.46 \%$ & $-0.95 \%$ & $-0.49 \%$ \\
$1860-1877 \ldots \ldots \ldots$ & $1.33 \%$ & $1.48 \%$ & $2.43 \%$ \\
$1877-1895 \ldots \ldots .$. & $1.90 \%$ & $2.28 \%$ & $3.75 \%$ \\
\hline
\end{tabular}

SOURCES: Coatsworth (1990), p. 83.

In spite of these problems, the cotton industry was able to grow during this period. Table 2 presents some of the data given by Alamán to prove his point, and shows a pattern of continuous growth in the textile industry. From 1837 to 1845 , cloth production increased by an extraordinary $1361 \%$.

Jan Bazant's calculations show that the Mexican textile industry of those years compared relatively well in terms of efficiency with the British and American industries. According to the Semanario de la Industria Mexicana, between 1841 and 1842 capital-labor ratios in the Mexican textile industry were 20 spindles per worker, around the same as for American workers in $1830^{42}$. However, the prices of the products were very different from

4 Atack and Passell (1994), pp. 185-188.

42 By 1840 each American worker handled 31 spindles on average, and 38 spindles in 1850. Jan Bazant (1964), pp. 55-56 


\section{TABLE 2}

Growth of the Mexican Cotton Textile Industry

\begin{tabular}{|c|c|c|c|c|}
\hline Year & $\begin{array}{c}\text { No. of } \\
\text { Factories }\end{array}$ & $\begin{array}{c}\text { No. Active } \\
\text { Spindles }\end{array}$ & $\begin{array}{c}\text { Yarn } \\
\text { (tons) }\end{array}$ & $\begin{array}{c}\text { Cloth Pieces } \\
\text { (1000's) }\end{array}$ \\
\hline $1837 \ldots \ldots \ldots \ldots \ldots \ldots \ldots$ & & & & 45 \\
\hline $1838 \ldots \ldots \ldots \ldots \ldots \ldots \ldots$ & & & 29 & 109 \\
\hline 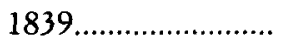 & & & 15 & 125 \\
\hline $1840 \ldots \ldots \ldots \ldots \ldots \ldots \ldots$ & & & 257 & 88 \\
\hline 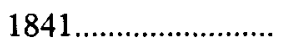 & & & 467 & 196 \\
\hline $1842 \ldots \ldots \ldots \ldots \ldots \ldots \ldots \ldots \ldots \ldots \ldots \ldots$ & & & 358 & 218 \\
\hline 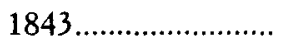 & 59 & 106,708 & 3,738 & 327 \\
\hline $1844 \ldots \ldots \ldots \ldots \ldots \ldots \ldots \ldots$ & & 112,188 & & 508 \\
\hline $1845 \ldots \ldots \ldots \ldots \ldots \ldots \ldots \ldots \ldots \ldots \ldots \ldots$ & 55 & 113,813 & 1,317 & 657 \\
\hline $1853 \ldots \ldots \ldots \ldots \ldots \ldots \ldots$ & & & 3,348 & 875 \\
\hline $1850-1857 \ldots \ldots \ldots \ldots$ & 48 & 119,278 & 3,351 & 727 \\
\hline $1862 \ldots \ldots \ldots \ldots \ldots \ldots$ & 57 & 133,122 & 3,615 & 1,259 \\
\hline $1879 \ldots \ldots \ldots \ldots \ldots \ldots \ldots \ldots \ldots \ldots \ldots \ldots \ldots \ldots$ & 89 & 253,594 & 2,925 & 3,255 \\
\hline
\end{tabular}

Sources: Alamán (1843), Table No. 5, Alamán (1846), Tables Nos. 2, 3, 4; México, Ministerio de Fomento (1857); Pérez Hernández (1862), pp. 136-139; Busto (1880); México, Dirección General de Estadistica (1894). Note: A cloth piece (pieza de manta) was a piece of unbleached cloth one vara wide and between 30 and 36 varas long. A vara equals 0.8359 meters. Bazant (1964), pp. 43-44.

those of the United States. A report on Mexico published in 1846 that «cotton goods which sell in the United States for six cents per yard, are worth thirty cents in Mexico» ${ }^{43}$. According to the author of that report, «this results from the high price of the raw material, which sells from forty to fifty cents per pound, and from the circumstance that all the machinery is imported and transported by land at an enormous costs; and also to the difficulty and delay of repairing it, when it breaks down» ${ }^{44}$.

Bazant's calculations present the cotton industry as a profitable one. They show that in 1843 the profit rates for the industry as a whole were $10 \%$ per piece of cloth produced, while for La Constancia they were $20 \%$ per piece of cloth ${ }^{45}$. However, Walker's study of the Miraflores mill sug-

${ }^{43}$ Farnham (1846), p. 29.

44 Farnham (1846), p. 29.

45 Bazant (1964), pp. 64-72. Interests rates in the period were around 10 to 12 per cent. 
gests that the prosperity of a textile mill depended more on its owners speculation in the cotton market than on its productivity ${ }^{46}$.

\section{GROWTH OF MEXICAN TEXTILE INDUSTRY FROM 1843 TO 1879}

The period between 1846 and 1867 was particularly difficult for Mexico. Even the country's survival came into question. In 1846 Mexico lost half of its territory to the United States. Furthermore, in 1847 a secessionist civil war broke out in the state of Yucatan that was not quelled until the 1850 s. Then, from 1857 to 1860 , the so called «Three Years War» between Liberals and Conservatives caused much destruction. In 1862, Napoleon III's troops landed in Veracruz. In 1864 Mexican Conservatives gave Maximilian the throne of Mexico, and conflict continued until 1867, when the Liberals deposed Maximilian. Peace was then more or less reestablished, though not entirely. In 1876 Porfirio Díaz seized power to rule the country until 1910.

According to Jan Bazant, Dawn Keremitsis, and Walther Bernecker, the modern textile cotton industry was formed in only some fifteen years, between 1830-1845, and by the mid 1850's the highest point of industrial expansion was reached ${ }^{47}$. After that, progress became far slower, stopping before the end of the decade, not to resume until 1880. Yet, Mexican imports of capital goods and machinery from 1845 to 1879 , as shown in Figure 1, tell a story of more industrialization during this period than in the supposed heyday of the industry between 1839 and $1845^{48}$.

For Keremtisis the survival of the textile industry during these years of foreign invasions, a major civil war, and slow-growing population was in itself remarkable ${ }^{49}$. It is even more remarkable that in fact the industry actually grew. The total number of looms and spindles grew by $138 \%$ and $241 \%$ respectively between 1843 and 1879 . At least part of this growth

46 Walker (1991), pp. 183-219.

47 Bazant (1964), p. 31, Keremitsis (1973), p. 55, and Bernecker (1992), p. 251.

48 In 1862 Mexican imports of British products accounted for $43 \%$ of total imports. (Imports from the U.S. and France were each of them $17 \%$ of total imports). Pérez Hernández, (1862), p. 154. Imports from the U.K. must have represented more than $43 \%$ of total imports of raw iron and machinery early in the century, since the United States and France were not competitive with the U.K., then in these products. Yet, as the century advanced, the share of imports of these kinds from the United States and Germany grew. In $1888.89,54 \%$ of the iron and steel imported by Mexico came from the U.S., $22 \%$ from Great Britain, 15\% from Germany and 7\% from France. García Cubas (1893), pp. 62-65.

49 Keremitsis (1973), p. 55. 


\section{FIGURE 1}

Macbinery and Millwork imported by Mexico from the UK $(£)$

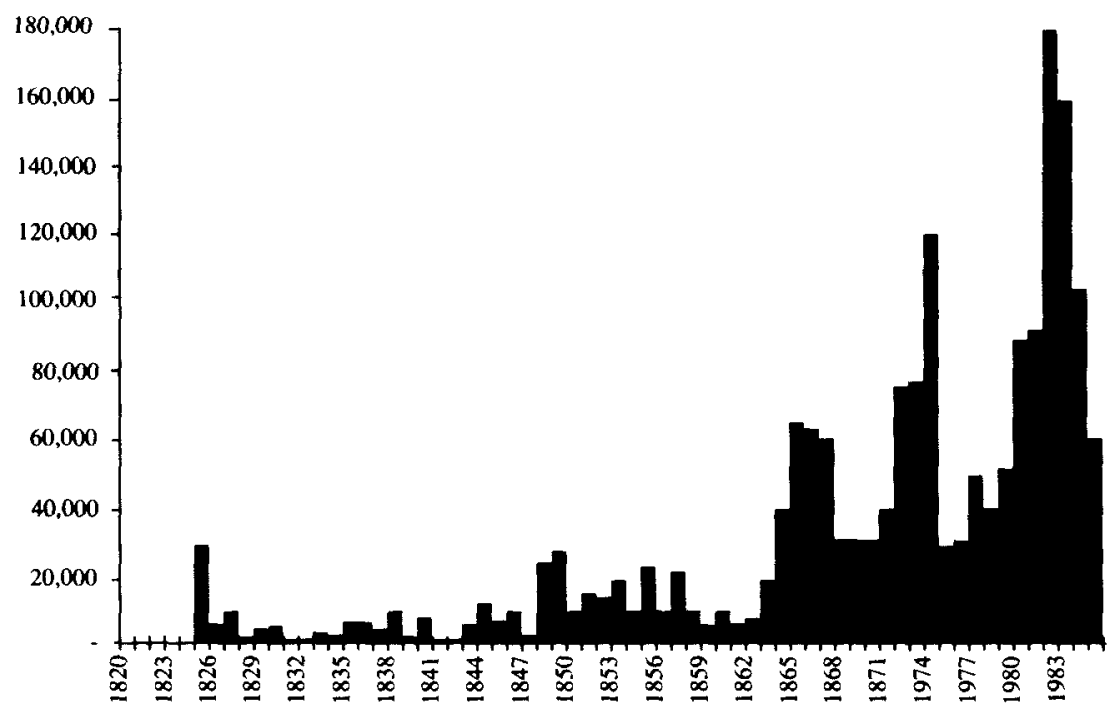

SourCE: U.K. Parliamentary Documents, Return to an Order of the Honourable The House of Commons Several Issues.

took place between 1843 and 1862 when the number of spindles increased by $25 \%$ (See Table 2). Furthermore, the average firm grew, increasing its number of spindles by $58 \%$ and its number of looms by $126 \%$. But the industry grew more because the number of firms increased, rather than because of growth in the size of firms.

In spite of their growth, the average size of Mexican mills fell below their American counterparts. In 1843, Mexican mills, in terms of spindles per mill, were not much smaller than United States firms in 1831. In contrast, by 1879 , average spindles per mill in the Mexican industry were only $20 \%$ of what American mills had on average in $1880^{50}$.

${ }^{50}$ However, if one compares Mexican mills to factories in the South and West of the United States, the differences are less pronounced. U.S. $10^{\text {th }}$ Census 1880 , Report of Manufactures of the United States, [Caroll, Wright], Report on the Factory System of the United States, June $1^{\text {st }} 1880$. 


\section{TECHNOLOGICAL PROGRESS}

The cotton textile industry not only grew between 1843 and 1879 , it also modernized. As we have seen, the industry successfully integrated spinning and weaving. Even more important was the complete transformation in the sources of power used. Table 3 shows that in $1843,37 \%$ of the firms used men or mules as their source of power; only $3 \%$ ran on steam. By 1878 no textile mill operated with animal power. Instead, $64 \%$ of the factories employed steam power. Of the total manta produced, only $2 \%$ was made using steam in 1843 , but $70 \%$ in 1878 . While in 1843 only $56 \%$ of the firm were using water power, by 1878 this figure rose to $91 \%$. More than half of the firms $(55 \%)$ combined steam and water power.

To have some measure of the different efficiency of the various sources of power, I calculated the average value of production, per peso of labor, in 1843. Human-powered mills produced 2.75 pesos, steam-powered 3.05 pesos, mule-powered 3.43 and water-powered 4.27 pesos, per peso of labor ${ }^{51}$. Using steam as a sole source of power was prohibitively expensive since the lack of coal forced firms to burn wood. Before the introduction of electricity, the best combination of power sources in Mexico was steam and water. Water was used most of the time, but it was complemented with steam during the dry season. These cost estimates explain why power sources changed to the prevalent use of a combination of water and steam in 1878 .

Technological progress appears to have had a positive impact on mill productivity levels. Although productivity has not been measured for the specific period studied here, Haber's and Razo's measurements of labor productivity and total factor productivity ${ }^{52}$ for the period 1850 to 1890 indicate that they increased by $3.3 \%$ and $2.6 \%$ respectively per year when production is measured by physical output ${ }^{53}$.

${ }^{51}$ The calculation for steam is not very reliable because there was only one observation.

52 Labor productivity is output produced per worker, total factor productivity is output produced per units of several inputs, weighted by their shares in the production process. In Razo's and Haber's calculation of total factor productivity for the textile industry inputs considered are: capital, measured by the number of spindles, and labor, measured by the number of workers. Output is measured by the meters of cloth produced, for the estimates here quoted.

${ }^{53}$ Razo and Haber (1998), p. 18. 


\section{TABLE 3}

Mexican Textile Industry Energy Sources (1843-1878)

\begin{tabular}{|c|c|c|c|c|c|}
\hline & $\begin{array}{c}\text { Firms } \\
(\%)\end{array}$ & $\begin{array}{c}\text { Spindles } \\
(\%)\end{array}$ & $\begin{array}{l}\text { Looms } \\
(\%)\end{array}$ & $\begin{array}{c}\text { Cloth } \\
(\%)\end{array}$ & $\begin{array}{l}\text { Yam } \\
(\%)\end{array}$ \\
\hline \multicolumn{6}{|l|}{1843} \\
\hline Men..................... & 13.6 & 0 & 30.7 & 33.1 & 0 \\
\hline Mules ................. & 23.7 & 5.8 & 16.5 & 20.8 & 6.8 \\
\hline Water ................. & 55.9 & 84.5 & 46.3 & 43.7 & 83.3 \\
\hline Steam ................ & 3.4 & 2.3 & 1.8 & 2.3 & 3.3 \\
\hline Water \& Steam. & 0 & 0 & 0 & 0 & 0 \\
\hline N/A .................... & 3.4 & 7.5 & 4.6 & 0 & 6.6 \\
\hline Total ...................... & 100.0 & 100.0 & 100.0 & 100.0 & 100.0 \\
\hline \multicolumn{6}{|l|}{1878} \\
\hline \multicolumn{6}{|c|}{ As a percentage of total } \\
\hline Men .................... & 0 & 0 & 0 & 0 & 0 \\
\hline Mules ................. & 0 & 0 & 0 & 0 & 0 \\
\hline Water ................. & 36.0 & 24.1 & 27.8 & 29.9 & 55.0 \\
\hline Steam .................. & 9.0 & 7.2 & 10.7 & 12.8 & 2.1 \\
\hline Water \& Steam & 55.1 & 68.7 & 61.5 & 57.3 & 42.9 \\
\hline Total.................... & 100.0 & 100.0 & 100.0 & 100.0 & 100.0 \\
\hline
\end{tabular}

SOURCES: Alamán (1843) and Busto (1880).

\section{EXPLAINING GROWTH BETWEEN 1843 AND 1879}

Industrial growth between 1843 and 1878 is difficult to explain given the difficult economic and political conditions then. The central government's lack of control and its inability to guarantee security, even on the most important highways, greatly increased transportation costs. Roads were bandit-infested. Accounts of the period tell, for example, that in one single day in 1861, the stagecoach from Mexico City to Puebla was robbed three times. In 1865, in two weeks, there were four major robberies along the highway from Orizaba, Veracruz, to Mexico City. Apparently, members of the army themselves robbed like bandits ${ }^{54}$.

Government's inability to provide security forced firms to assume considerable costs in protecting their property by themselves. From 1869 to

${ }^{54}$ Haber (1989), pp. 21-22. 
1870, Col. Albert S. Evans traveled through Mexico visiting several textile factories. According to his account, La Purísima Concepción, and Hércules, both in the state of Querétaro, stood in an «enclosure, with high walls (...) and [ were] guarded all the time by watchmen in full military uniform, armed and drilled in the best modern style» 55 .

Additionally, historians have considered that tariff policy changed for the worse. «The friendly attitude of the Mexican government toward industry which characterized the period from 1830 to 1845 also was considerably modified between 1850 and $1880 \gg{ }^{56}$. From 1855 on, the country was mostly under Liberal rule. The Liberals advocated freedom of trade and the promotion of the interests of the merchant and the capitalist agricultural class, decentralization and limitation of the national government, and the elimination of the «feudal» privileges of the church and the military ${ }^{57}$. Table 3 shows that there was a reduction in the tariffs on cotton manufactures in $1856^{58}$. However, the effect of this reduction was not unambiguously negative for the textile industry, as Keremitsis seems to believe, since the government also removed the prohibition on the imports of raw cotton.

A raw estimate of the effects of the Liberal's reduction on tariffs from 1855 to 1856 shows its net effect was positive. In order to estimate the impact of the tariff change, we need to calculate the difference between the drop in prices of manufactured goods caused by the tariff reduction, and the fall in production costs that the decrease in the tariff for raw cotton generated. In 1843 the price of a piece of manta (of 30 varas) was $\$ 7.0059$. Therefore, the reduction in duty from $\$ 0.10$ to $\$ .03$ per vara of cotton cloth implies that the ad valorem duty changed from $43 \%$ to $13 \%$. This reduction in the duty would have meant that cloth prices in Mexico dropped $21 \%$. In 1843 , a year when raw cotton imports were prohibited, the average price of a quintal of cotton was $\$ 34^{60}$. Alamán in the Report of 1845 wrote that the price of a quintal of foreign cotton with no duty in Veracruz was $\$ 13.37$, and $\$ 18.37$ in Mexico City ${ }^{61}$. Replacing prohibiton with a tariff of $\$ 1.50$ per quintal of raw cotton would reduce the price from $\$ 34$ to $\$ 17.37$ (average price), which implies a drop of $49 \%$ in the price of cotton.

55 Evans (1879), p. 222.

${ }^{56}$ Keremitsis (1973), pp. 41-42.

57 Keremitsis (1973), p. 38.

${ }^{58}$ This was pointed out by Cosío Villegas (1932), pp. 13, 43, and 92.

59 Alamán (1843), p. 21 and Bazant (1964), p. 65.

${ }^{60}$ Bazant, (1964) p. 65. One quintal is equal to 100 pounds.

61 Alamán (1846), p. 48. 


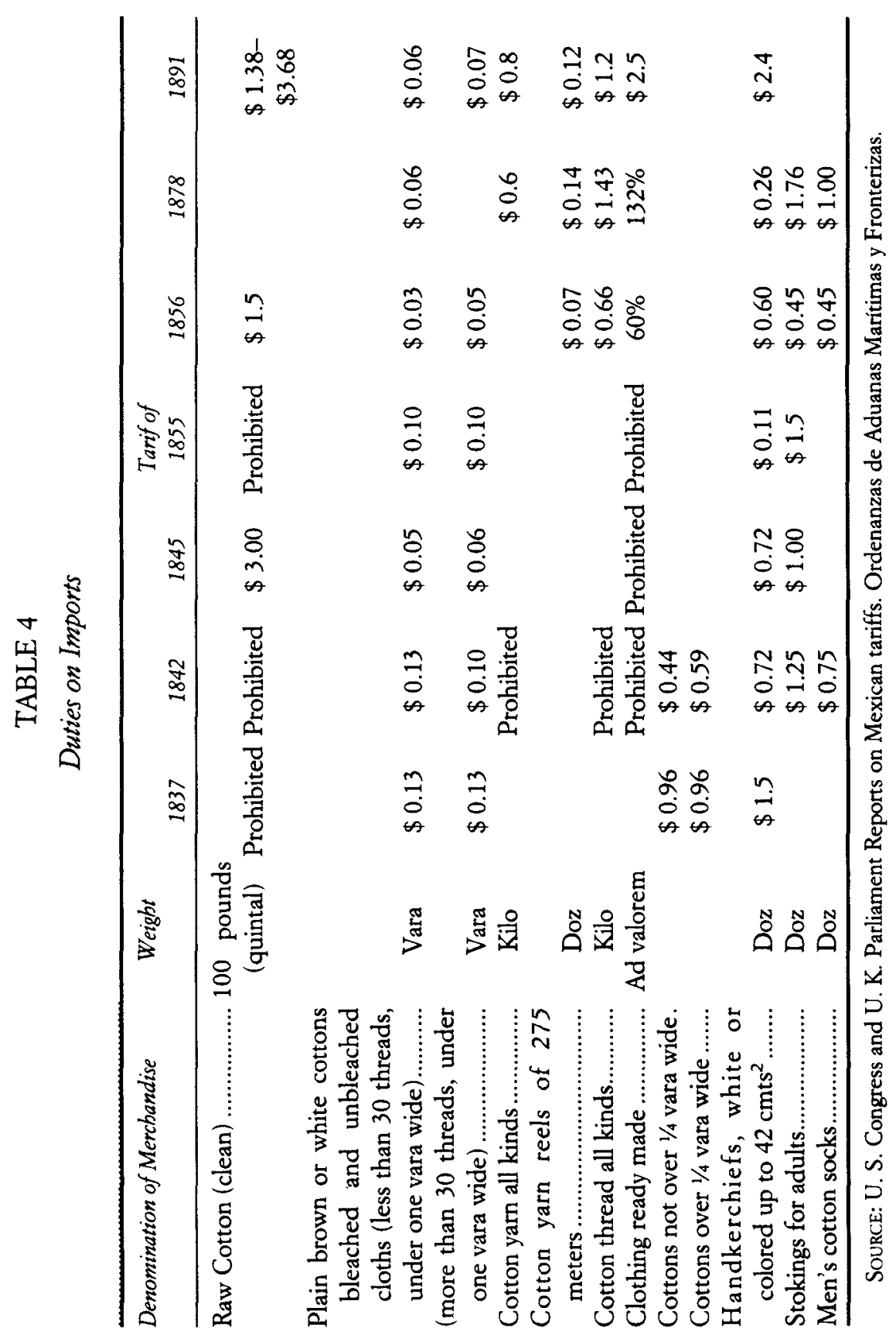


In order to calculate the change in the effective protection the two tariff regimes granted, we need to know the percentage of raw cotton in total production costs of manufactured textile goods. If we assume that cotton accounted for $72 \%$ of costs - as the regressions on the 1893 data show - then the Liberal tariff change would have generated a $35.2 \%$ reduction in the costs of manufacturing cotton textiles ${ }^{62}$. If we consider Jan Bazant's estimates, in which cotton accounts for $47.6 \%$ of costs, then the tariff reduction would have diminished the cost of cotton manufactures by $23.3 \%$. In the first case, profits for the textile industry would have increased by $14.2 \%$, and in the second case by $2.3 \%$. This shows that tariff reduction did not hurt the textile industry, but most likely helped it. It suggests that a bad protectionist policy can be worse for industrial development than a more liberal one.

In addition, the American Civil War had a positive effect on the Mexican cotton textile industry, since it by increased the price of international cotton manufactures and decreased the price of raw cotton. The blockade of the South by the Union -effective in Texas in mid 1861 - forced the Confederates to channel cotton exports through the Mexican border. From 1861 to 1865 millions of bales of cotton crossed through the Brownsville-Matamoros, Eagle Pass-Piedras Negras and Laredo-Nuevo Laredo border posts ${ }^{63}$. It was then re-exported through the port of Bagdad (near Matamoros). This trade generated enormous profits among Mexican merchants and rapid growth in the Northeast ${ }^{64}$. Monterrey became a «free depot of cotton,» in that any number of bales could be deposited there with a duty paid only upon shipment to Matamoros or towards the interior; the city owed its future prosperity to its growth in this period ${ }^{65}$.

The increased supply of raw cotton and the increased demand for cotton manufactures from the embattled American South made it possible for Mexican textile mills to export their products. In 1861-62, the Ibernia factory in Saltillo produced approximately $\ll 11,500$ pieces of common brown sheeting called manta, which were sold to the Southerners for $\$ 4.50$

${ }^{62}$ The production function that came out of a regression on the 1893 data showed that capital accounted for $11 \%$ of the costs, Labor for $17 \%$, Cotton for $72 \%$ and Fuel for $1 \%$. (See footnote 32 ).

${ }^{63}$ Tyler (1973), p. 121.

b4 Cerutti (1992), pp. 74-87.

${ }^{65}$ Tyler (1973), p. 110. 
each» ${ }^{66}$. From importing almost six million pounds in 1858 , Mexico exported to the United States five million pounds in 1861, and even more to the United Kingdom. In 1864, the United States (the North) imported fifteen million pounds of cotton from Mexico, which represented $56 \%$ of its total raw cotton imports ${ }^{67}$.

Thomas Schoonover is right in believing that the American Civil War had positive effects on the Mexican textile industry ${ }^{68}$. However, he is wrong in thinking that the cotton exported by Mexico to the United States in this period was grown in Mexico ${ }^{69}$. A simple comparison of the figures for cotton exports with those for cotton production shows that the dramatic growth in cotton production in Mexico that would have been necessary to export such quantities was simply impossible, given that the country was not even self sufficient in cotton by 1860 . The difference between Mexico's textile mills' raw cotton consumption and national production was of approximately 4 million pounds in 1845 and 2.5 million pounds in $1859^{70}$. Furthermore, sufficient information exists that Mexico was importing vast amounts of cotton from the South ${ }^{71}$.

Furthermore domestic demand for the period 1843-1877 must have increased, giving an additional boost to textiles' production. While population grew at even a lower rate from 1845 to 1860 than in the previous 45 years, its pace of growth considerably raised from 1860 to 1877 . Income per capita, which according to Coatsworth's estimates continued to fall from 1845 to 1860 , began to recover after that date growing at an average rate of $1.48 \%$ from 1860 to 1877 (See Table 1). On average, population grew by $0.90 \%$ and income per capita by $0.33 \%$ from 1845 to 1877 .

\section{THE GEOGRAPHICALLY DISPERSED NATURE OF INDUSTRIAL GROWTH}

The Mexican textile industry's growth between 1843 and 1879 was accompanied by regional dispersion. In $1843,64 \%$ of the firms $57 \%$ of

${ }^{66}$ Charles Lempriere, Notes in Mexico in 1861 and 1862: Politically and Socially Considered (London: Longman, Green, Longman, Roberts, and Green, 1862), p. 133, in Tyler (1973), p. 110.

${ }^{67}$ U. S. Treasury. Commerce and Navigation Reports. Several issues and U.K. Parliamentary Documents, Return to an Order of the Honourable The House of Commons. Several Issues.

${ }^{68}$ Schoonover (1992), pp. 86-109.

${ }^{69}$ Evans (1879), p. 64.

${ }^{70}$ Evans (1879), p. 64.

71 Tyler (1973), pp. 98-128. 
spindles and $65 \%$ of looms) were located in Mexico City, the state of Mexico, and Puebla. By 1879 only 33\% (46\% of spindles, $44 \%$ of looms) were located there. In 1843 there were firms in only eight states, whereas by 1879 almost every state had its own firm. The regional dispersion of the industry was well underway before $1862^{72}$.

Mexico's geography, devoid of navigable rivers and full of mountains, made transportation very difficult ${ }^{73}$. The relatively high transportation costs in Mexico explains the geographical dispersion of the Mexican textile industry during its early development. Most transportation was carried on by mules and ox-carts until the 1880's. In addition to the problems caused by nature, inter-state tariffs - the alcabalas - raised transportation costs even more. It is difficult to exaggerate the importance of alcabalas as an obstacle to economic growth. When in February 1852 the governor of the state of Veracruz reestablished the alcabalas, abolished since 1847, merchants complained harshly. A letter with more than a hundred signatures sent by the «Merchants of Orizaba» to the Congress of the State of Veracruz declared:

... when the Spanish domination ended, the system of indirect taxes remained in practice, despite the considerable expenditures that it demands, and that the arbitrariness and vexations that it brings are very opposed to the liberal system that the Republic adopted; since we were used to it, and since the doctrines of economists had not circulated but among a very few number of Mexicans, the people said nothing and paid the indirect taxes to which it was used to. But later (...) it started to claim for a reform of the public finance system (...). In effect in the year of 1847 the people of Veracruz not being able to stand the arrogance and haughtiness of the [alcabala] guards, the abuses and frauds of all the employees, and not being able anymore to see with indifference the great cost that demands the collection of the indirect taxes, asked with energy that these were substituted by another system less expensive and more in accordance with the principles of freedom that rule us.

In effect (...) Don Juan Soto, then governor of the state, had the glory of being the first in destroying the indirect taxes and freeing the people of Veracruz from the burdens of such a costly system. In that period, even though we were experimenting the disturbances that come with a foreign war, as the hindrances to which commerce was subject ceased, and as the

72 Alamán (1843), Alamán (1846), Pérez Hernández (1862) and Busto (1880).

73 Mexico's high transportation costs are evident in Coatsworth's measurements of railroad social savings in Mexico, especially when compared to the small effect of railroads that Fogel found for the United States. See Coatsworth (1990b), p. 195 and Fogel (1964), pp. 217-220. 
means to trade were facilitated, a great movement was generated, several commercial establishments appeared (...). The war with the United States ended and as the alcabalas to trade were not reestablished, it became a source of public richness that prospered day to day, in such a way, that in the localities where before there was only stagnation and misery, later we could see active movement and abundance. With the abolition of the alcabalas (...) the people of Veracruz had the satisfaction of seeing the expenditures of the state reduced to almost half of what they were before (..). But unfortunately when all the Veracruzans looked with satisfaction this gratifying picture that appeared in every town of the state, a new law reestablishing the hated alcabalas, came to throw to the ground trade and to end the hopes of prosperity and growth ${ }^{74}$.

In the questionnaire Emiliano Busto sent to several manufacturing companies in 1877 , entrepreneurs replied that alcabalas were the single most damaging policy affecting their firms. The owner of La Estrella mill in Coahuila, for example, wrote: »the alcabalas are a true gangrene to the social body, something even more dangerous than the turbulence to which we are prey so frequently, and if they are not suppressed, they will crush the few industries that some few daring men, who want to see their country full of factories and their fellow citizens employed (...), support» ${ }^{75}$. Despite the opposition, the alcabalas were not abolished until 1896, although formally prohibited by the 1857 Constitution. Even though it was evident that the existence of inter-state barriers greatly damaged economic growth, governments could not abolish them due to institutional weakness and fragmentation.

Transportation costs derived from nature, from insecurity on the roads, and from alcabalas limited the markets accessible to firms, often reducing them to only the state in which they operated. High transportation costs and inter-state tariffs that reduced market size make for a more dispersed pattern of firms. This is exactly the pattern of industrialization that we find in Mexico ${ }^{76}$.

In 1843 , when there were very few mills, the industry appeared more concentrated than later when there were more factories. By 1879 , the

${ }^{74}$ Archivo Municipal de Orizaba, Box 2-68, 1952, «Exposición que los Comerciantes de Orizaba elevan al $\mathrm{H}$. Congreso del Estado solicitando la estinción del derecho de alcabalas», June 2, 1852.

${ }^{75}$ Busto (1980), Volume II, p. 319.

${ }^{76}$ The extraordinary dispersion of the Mexican cotton industry could also have resulted from the type of power sources it most conveniently used. The use of water as a source of water power together with the use of wood as fuel could explain a dispersed pattern of location generated by mills establishing in sites close to water sources and forests. If 
industry had dispersed in a flat pattern all over the country. As railroads were opened, the industry re-concentrated, but never as much as the American industry did (see Figures 2 and 3) ${ }^{77}$. The geographically scattered nature of Mexico's textile industry development contrasted not only with that of the United States but also with that of Great Britain, where the industry also grew in a more regionally concentrated pattern ${ }^{78}$.

\section{FIGURE 2}

\section{Lorenz curves for the Mexican Cotton Textile Industry}

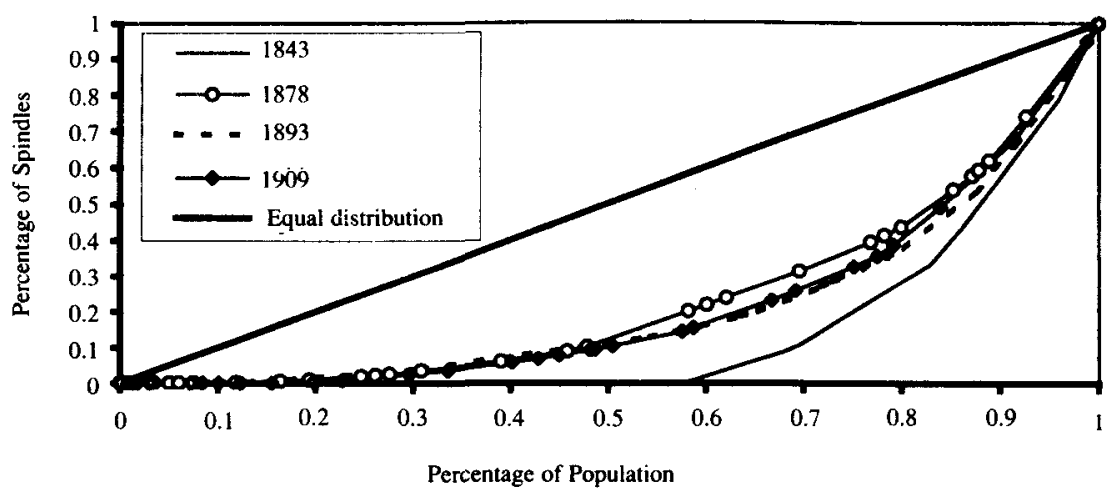

SOURCE: See Tables 2, 4, and 12.

Regional dispersion demonstrates the diffused nature of the national market. Regions with comparative advantages over others in terms of cotton, energy, and labor costs did not concentrate the industry as they did in the United States. Relatively efficient mills coexisted with very inefficient ones because high transport costs provided protected markets for relatively inefficient or less than optimally sized firms. Furthermore, regional dis-

this had happened the industry would have located in those regions where water power and wood were cheaper, which is not what evidence for the Mexican textile industry shows.

77 From 1880 to 1930 the American industry shifted from New England to the south and appeared to be dispersing, but by 1930 it had concentrated to the 1880 level. See: Kane (1988), p. 1-3.

${ }^{78}$ For a long period of time much of the textile industry was concentrated in New England in the United States and in Lancashire in England. Even when the American textile industry moved south, it never moved west, and generally remained more concentrated than its Mexican counterpart. 


\section{FIGURE 3}

\section{Lorenz curves for the United States Cotton Textile Industry}

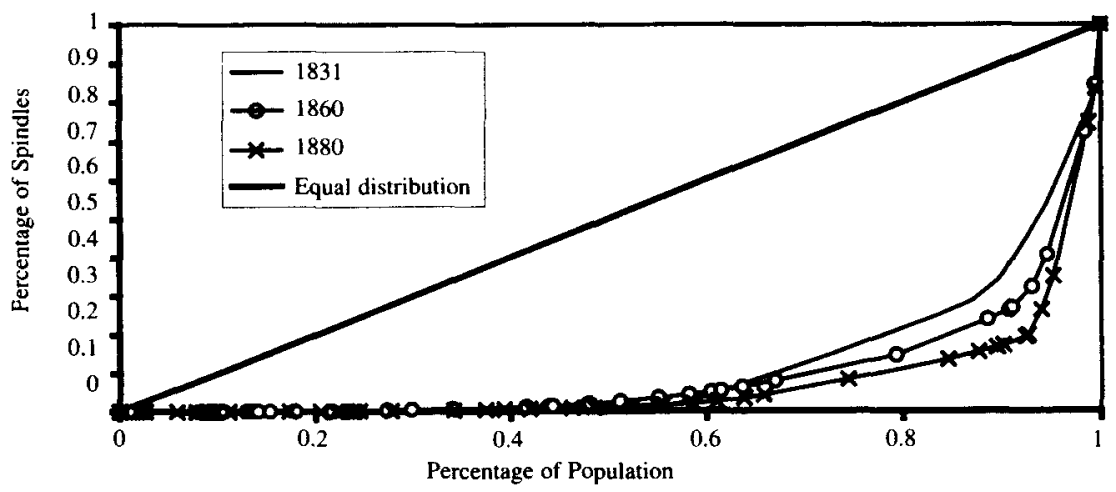

SOURCE: U.S. Department of Commerce, Bureau of the Census, Report of Manufactures, 1880: $10-15,24-37$.

persion reduced the externalities a «big push» could have generated if the industry had sufficiently accumulated in particular regions ${ }^{79}$.

Cultivation of cotton in Mexico followed a similar pattern of geographical distribution to that of the textile industry; dispersion from 1843 to 1879 , concentration afterwards (See Figure 4). Cultivation of cotton was always more concentrated geographically than the textile industry because suitable locations for the cultivation of cotton are generally more limited than those required for the establishment of mills. Yet, it did not pose a limit to the dispersion of the industry. While some regions must have been more appropriate than others for cotton growing, high transportation costs made it profitable to produce it in a wide array of regions in order to supply the local mills. Thus, cotton cultivation dispersed from being cultivated in only five states in 1843 , to been grown in twelve states by 1879. The share produced in Veracruz, where cotton was mostly grown, diminished from $52 \%$ to $42 \%$ in this period.

Reduction in transportation costs generated a more radical transformation in cotton production than in textile manufactures in terms of the geographical distribution of production. After 1892, between $80 \%$ and $90 \%$ of cotton produced in Mexico was grown in La Laguna district, a region

\footnotetext{
${ }^{79}$ See Murphy, Shleifer and Vishny (1989), pp. 1003-1025.
} 


\section{FIGURE 4}

\section{Lorenz Curves for Cultivation of Cotton in Mexico}

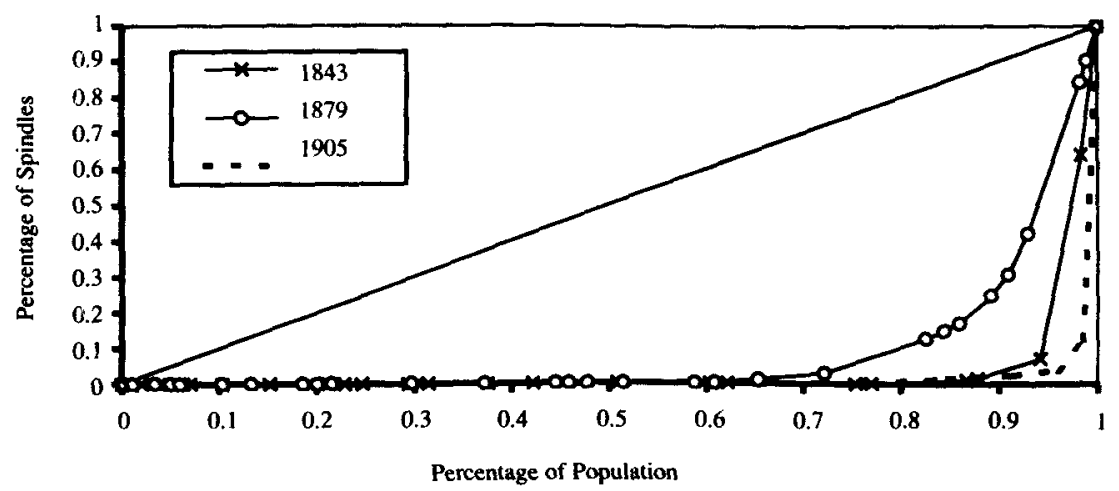

Sources: Alamán (1843), Tables 3 and 4, Busto (1879), Table 30, Clark (1909), p. 28.

between Durango and Coahuila connected to the rest of the country in 1888 by the Central Railway Company ${ }^{80}$. Once railways were built, irrigation improvements, together with the introduction of the American cotton seed, allowed this region to profit from its comparative advantages for cotton production, that included climatic conditions unsuitable for the development of the boll weevil that damaged cotton crops elsewhere in Mexico ${ }^{81}$.

Why did the industry's geographic concentration change so little after railroads were built, and alcabalas abolished, particularly when compared to cotton cultivation? Changes in industrial localization tend to take place very slowly as a result of «learning by doing» and the capital loss companies have to incur in order to move, which are greater than those experienced in agriculture. Thus, path-dependency plays a large role in industrial localization. In 1879 , buildings represented $54 \%$ of the reported value of all textile mills, the rest was the value of its machinery ${ }^{82}$. This capital would have been lost if mills were relocated. Given that mills had already been established, they continued operating, unless great location disadvantages existed that made them go bankrupt. There was no «boll-weevil» in cotton manufacturing that forced ill-located textile mills to go out of business.

\footnotetext{
${ }^{80}$ Plana (1996), pp. 123-128, Clark (1909), p. 27.

${ }^{81}$ Plana (1996), pp. 219-246, Clark (1909), pp. $27-33$.

${ }^{82}$ Busto (1879), Table 2, pp. 1-4.
} 
In the American textile industry relocation from the New England to the South took place very slowly. As Gavin Wright explains «Even after the acceleration of the 1870s, it took at least a half-century for the South to gain the market position made possible by the labor-cost advantage ${ }^{83}$. The northern industry continued to grow, although at a slower rate than in the South. Its collapse did not become visible until the early 1920's, when the number of mills began to decline sharply ${ }^{84}$. This indicates how slowly locational advantages make an industry move away from those regions where investment is already in place. Further work needs to be undertaken in order to answer this question fully.

\section{CONCLUSION}

The early appearance of Mexican cotton textile industry and its steady growth throughout the 19th century, tell us of the possibility of a successful industrialization process in Mexico in that period. Three conditions that were not present in the rest of Latin America explain its earlier industrial growth. First, its relatively large population, concentrated in the center of a mountainous country far away from the sea-ports, that provided the market necessary for industry to develop. Second, a tradition in the artisanal textile production which generated political support for protectionist policies. And third, a historical juncture between 1830 and 1840 when government, under the influence of statesmen such as Lucas Alamán, and industrialists such as Estevan de Antunano, provided both tariff protection and means of finance for the textile industry through a development bank, the Banco de Avío.

From 1830 to 1879 Mexican textile industry changed from production carried on using hand spindles and looms from the Colonial era, to water and steam powered machinery. Furthermore, the industry vertically integrated the spinning and weaving processes in the decades between 1843 and 1879. Contrary to the commonly held views, the growth of the industry did not end around 1845 but continued through 1879, fostered in part by the effects of the American Civil War on the Mexican economy. Growth . occurred even in the tumultuous period from 1843 to 1862 . Yet despite this growth, the Mexican textile industry did not profit from its early establishment and fell behind its counterparts in the rest of the world.

\footnotetext{
${ }^{83}$ Wright (1986), p. 124.

${ }^{84}$ Kane (1988), pp. 155-156.
} 
Institutional frailty made Mexican governments unable to provide a coherent industrial policy, as that designed by Alamán. Mexican governments could not even provide the basic ingredient for economic development: a «Rule of Law» that set efficient property rights ${ }^{85}$. Mexican governments, in permanent financial need, generated an institutional framework in which individual benefits and costs did not equate social ones ${ }^{86}$. Entrepreneurs who succeeded, such as Cayetano Rubio, were those capable of obtaining rents and privileges from the government, not those, such as Estevan de Antunano, who made investments in order to increase productivity levels.

Institutional frailty, in terms of time, strength and scope, prevented government from undertaking a protectionist policy that could foster industrial development. As long as a specific tariff schedule was not reliable in the long run, entrepreneurs could not base their investment decisions on it. Trade policy became an instrument by which governments gave monopoly power to particular groups that would give them political and financial support, such as the agiotistas, government lenders to whom the government sold raw cotton import permits. Finally, governments were unable to prevent smuggling, which limited their ability to grant actual protection to industry.

Protectionist policy, as it was undertook by Mexican governments in early $19^{\text {th }}$ century, harmed industry more than it helped it. The liberal reduction of import duties on raw cotton and cotton manufactures of 1856 , had a positive effect over textile industry, contrary to what historians until now have believed. Since raw cotton accounted for the majority costs for the textile industry, its tariff reduction compensated for the reduction in the duty on cotton manufactures.

There is perhaps no other historical episode better suited to refute the «dependentist» view of the economic history of Latin America than the history of the Mexican textile industry during the early $19^{\text {th }}$ century. Mexico did not suffer from a lack of protection to its industry. However, as the history of Mexican textiles shows, a badly undertaken protectionist policy can be as harmful to industrial development as lack of protection can be.

Institutional frailty hindered the development of financial markets in Mexico in the $19^{\text {th }}$ century. After the Banco de Avío closed its doors in

${ }^{85}$ North (1994), p. 581.

${ }^{86}$ North (1991), pp. 11-13. 
1842 , there was no institutional lending to industry until the 1880 s. Industrialists had to rely on informal mechanisms of raising capital, in most cases based on kinship networks of credit. Successful entrepreneurs were those who undertook speculative activities as part of their business such as money-lending to the government. The instability and underdevelopment of financial markets was the result of the lack of two preconditions the government was not able to meet due to its permanent fiscal deficits and constant debt defaults: the stabilization and broadening of short-term money-markets, and the creation of a relatively open internal market for public securities $^{87}$.

Institutional frailty limited Mexico's possibility to diminish its high transportation costs by an earlier introduction of railroads. Institutional uncertainty generated such a risky environment for investment that it limited the private sector from undertaking it. Institutional weakness made government unable to actively promote railroad construction. Additionally, it made governments unable to provide security on the roads, and widespread banditry further increased transportation costs. We can blame institutional fragmentation for the existence of inter-state tariff barriers that added to those transportation costs that resulted from nature. Even though the nation would gain by abolishing inter-state tariff barriers, federal governments were not strong enough - either fiscally and militarily - to impose the national good over that of regional interest groups that profited from these taxes. They were unable to coordinate a general removal of alcabalas that would help individual states surmount the «free-rider» problem, that would occur if each separately eliminated them. State governments poorly developed tax collection systems could not substitute alcabalas with other taxes that would allow greater economic growth. Alcabalas continued to exist until 1896 severely reducing market sizes accessible to firms.

These factors not only limited the levels of growth and technological change the industry experienced, but also shaped it in a peculiar way: it grew geographically dispersed. By 1879 there existed cotton mills in practically all the states of the Republic. This contrasts with the way the cotton textile industry developed both in the United States and in the United Kingdom. High transportation costs, a product of nature and of insecurity on the roads and alcabalas, generated a fragmented market that inhibited the Mexican textile industry from locating in the region that offered comparative advantages. The geographically dispersed nature of the industry

\footnotetext{
${ }^{87}$ Marichal (1997), p. 119.
} 
might have also prevented that the externalities that accrue from a «big push» develop as they would have done otherwise.

\section{BIBLIOGRAPHY}

Alamán, Lucas (1843): Memoria sobre el Estado de la Agricultura e Industria de la República en el año de 1843, Dirección de Agricultura e Industria, México, Imprenta de J. Lara.

- (1846): Memoria sobre el Estado de la Agricultura e Industria de la República en el año de 1845, Dirección de Agricultura e Industria, México, Imprenta de J. Lara.

AtaCK, Jeremy, and PASEll, Peter (1994): A New Economic View of American History, $2^{\text {nd }}$ ed., New York, W.W. Norton and Company.

Bazant, Jan (1964): Estudio sobre la Productividad de la Industria Algodonera Mexicana en 1843-1845, México, Sobretiro del Volumen VII de la Colección para la Historia del Comercio Exterior.

BATOU, Jean (1991): «Muhammad-'Ali's Egypt, 1805-1848. A command economy in the 19th Century?», in Jean Batou (ed.) Between Development and Underdevelopment. The Precocious Attempts at Industrialization of the Periphery 1800-1870, Geneve, Librarie Droz, pp. 181-218.

BERNECKER, Walter L. (1992): De Agiotistas y Empresarios, México, Universidad Iberoaméricana.

Busto, Emiliano (1880): Estadísticas de la República Mexicana: Estado que guardan la agricultura, industria, minería y comercio: Resumen y análisis de los informes rendidos a la Secretaría de Hacienda por los agricultores, mineros, industriales y comerciantes de la República y los agentes de México en el exterior en respuesta a las circulares del 10 de agosto de 1877. Anexo número 3 a la Memoria de Hacienda del año económico de 1877 a 1878, 3 vols., México, Imprenta de Ignacion Cumplido.

ButTerfiel, Carlos (1861): United States and Mexico. Commerce, Trade and Postal Facilitied between the Two Countries. Statistics of Mexico, 2nd. ed., New York, J.A.H. Hasbrouck \& Co. Printers.

CeruTtI, Mario (1992): Burguesía, Capitales e Industria en el norte de México, México, Alianza.

Clark, Graham W. A. (1909): Cotton Goods in Latin America. Part I, Cuba, Mexico, and Central America, Department of Commerce and Labor, Bureau of Manufactures, Washington, Government Printing Office.

- (1914): Cotton Goods in Japan. Department of Commerce and Labor, Bureau of Manufactures, Washington, Government Printing Office.

CuINe, Howard F. (1947): «The Aurora Yucateca and the Spirit of Enterprise in Yucatán 1821-1847», in Hispanic American Historical Review, 27, pp. 30-31.

COATSWORTH, John H. (1990a): «Decadencia de la Economía Mexicana, 1800-1860», in Los Orígenes del Atraso, México, Alianza, pp. 110-141.

- (1990b): «El Impacto Económico de los Ferrocarriles en una Economía Atrasada», in Los Orígenes del Atraso, México, Alianza, pp. 178-208. 
- (1979): «Características Generales de la Economía Mexicana en el Siglo XXX», in Enrique, Florescano (comp.), Ensayos sobre el Desarrollo Económico de México y América Latina 1500-1975, México, Fondo de Cultura Económica.

- (1981): Growth against Development. The Economic Impact of Railroads in $19^{\text {th }}$ Century Mexico, Delkab, Northern Illinois University Press.

Cosío Villegas, Daniel (1932): La Cuestión Arancelaria en México, Historia de la Política Aduanal III, México, Ediciones del Centro Mexicano de Estudios Económicos.

De Antuñano, Estevan (1837): Pensamientos para la Regeneración Industrial de México, Puebla, Imprenta del Hospital de San Pedro, Reimp. México, Porrúa, 1955.

Díaz CaYeros, Alberto (1995): Desamollo Económico e Inequidad Regional: Hacia un Nuevo Pacto Federal en México, México, Fundación Friederich Naumann, CIDAC and Miguel Ángel Porrúa.

Evans, Albert S. (1870): Our Sister Republic: A Gala Trip Through Tropical Mexico in 1869-70, Hartford Conn, Columbian Book Company.

Farnham, Thomas J. (1846); Mexico. Its Geography, its People and its Institutions, New York, H. Long \& Brother.

Fogel, Robert (1964): Railroads and American Economic Growth, Baltimore, John Hopkins.

García CuBAs, Antonio (1893): Mexico. Its Trade, Industries and Resources, Mexico, Typografical Office of the Department of Development, Colonization and Industry.

HABER, Stephen (1992): «Concentración Industrial, Desarrollo del Mercado de Capitales y Redes Financieras Basadas en el Parentesco: Un Estudio Comparado de Brasil, México y los Estados Unidos 1840-1930», Revista de Historia Económica, primavera-verano.

- (1997): «Financial Markets and Industrial Development: A Comparative Study of Governmental Regulation, Financial Innovation, and Industrial Structure in Brazil and Mexico 1840-1930», in Stephen Haber, How Latin America Fell Behind, Stanford, Stanford University Press.

- (1989): Industry and Underdevelopment, Stanford, Stanford University Press. IllaDES, Carlos (1989): «La Empresa Industrial de Estevan de Antuñano (1831-1847)» Secuencia, 15, Sept/Dic, pp. 28-46.

KANE, Nancy Frances (1988): Textiles in Transition, Technoloty, Wages and Industry Relocation in the U.S. Textile Industry 1880-1930, New York, Greenwood Press.

KEREMITSIS, Dawn (1973): La industria textil mexicana en el siglo XIX, Sepsetentas 61, México, Secretaría de Educación Pública.

MadDISON, Angus (1995): Monitoring the World Economy 1820-1992, Paris, OECD.

Marichal, Carlos (1997) «Obstacles to the Development of Capital Markets in Nineteenth-Century Mexico», in Stephen Haber (ed.) How Latin America Fell Bebind, Stanford, Stanford University Press, pp. 118-145.

México, Dirección General de Estadística (1857): Memoria 1857, México.

México, Dirección General de Estadística (1894): Anuario Estadístico de 1893, México.

México, Congreso. (1882): tr. J. Mastella Clarke, Mexico's Tariffs and Custom House Laws, México, Printing Office of «The Two Republics». 
México, Congreso. (1891): Ordenanza General de Aduanas Marítimas y Fronterizas, México, 12 de Julio de 1891.

MuRPhy, Kevin M.; SHLEIFER, Andrei, and VISHNY, Robert W. (1989): «Industrialization and the Big Push», Joumal of Political Economy, vol. 97, n. ${ }^{\circ} 5$.

North, Douglass, y ThOMAs, Robert Paul (1991): El Nacimiento del Mundo Occidental, 5. ${ }^{a}$ ed., Madrid, Siglo xxI.

- (1990): Institutions, Institutional Change and Economic Performance, New York, Cambridge University Press.

- (1994): «El Desempeño Económico a lo Largo del Tiempo», El Trimestre Económico, vol. LXI (4), n. ${ }^{\circ} 244$, octubre-diciembre, pp. 567-583.

Pérez Hernández, José M. ${ }^{2}$ (1862): Estadística de la República Mexicana, Guadalajara: Tipografía del Gobierno a cargo de Antonio de P. González.

POTASH, Robert A. (1983): Mexican Government and Industrial Development in the Early Republic: The «Banco de Avio», Amherst, The University of Massachusetts Press.

Plana, Manuel (1996): El Reino del Algodón en México. La Estructura Agraria de La Laguna (1855-1910), $2^{\text {nd }}$ ed., Monterrey, Facultad de Filosofía y Letras de la Universidad de Nuevo León.

Rosovsky, Henry (1966): Industrialization in two systems, essays in bonor of Alexander Gershenkron by a group of bis students, New York, Wiley.

SCHOONOVER, Thomas (1992): «El Algodón Mexicano y la Guerra Civil Norteamericano», in Carlos Marichal, La Economia Mexicana: Siglos XIX y XX, México, El Colegio de México, pp. 86-109.

Stein, Stanley J. (1957): The Brazilian Cotton Manufactures, Cambridge Ma., Harvard University Press.

Takajusa, Nakamura (1990): Economía Japonesa. Estructura y Desarrollo, México, El Colegio de México.

Thomson, Guy (1978): Economy and Society in Puebla de los Angeles 1800-1850, University of Oxford, mimeo.

Trujillo Bolio, Mario (1997): «La Fábrica La Magdalena Contreras (1836-1910)», en Carlos Marichal y Mario Cerutti (comps.), Historia de las Grandes Empresas en México 1850-1930, México, FCE y UANL, pp. 245-274.

Tyler, Ronnie C. (1973), Santiago Vidaurri and the Southern Confederacy, Texas State Historical Association.

U. S. Congress, Senate Executive Documents (1855-56): Comparative Tariffs. United States and Mexico, 34th Congress, 1st and 2nd. sessions, V. 19, 2819, pp.353-362.

U. S. Congress, House Executive Documents (1863-64): Commercial Digest: Mexico, 38th Congress, 1st session, V. 17, 1197, pp. 579-592.

U. S. Congress, House Executive Documents (1842-43): Statement, comparative, between the Mexican tariff of 1837 and the new tax for1842, 27th Congress, 3rd. session, V. 12, 419, pp. 217-265.

U. S. Department of Commerce, Bureau of the Census (1975): Historical Statistics of the United States Washington: GPO.

U. S. Treasury. Commerce and Navigation Reports, Several issues.

U. K. Parliamentary Documents. Return to an Order of the Honourable House of Common, Several Issues. 
U. K.(1878): Mexican and South American Import Duties on British Yarns, vol. LXVIII, pp. 622-746.

Walker W., David (1991): Parentesco, Negocios y Política. La Familia Martínez del Río en México, 1823-1867, México, Alianza Editorial.

WRIGHT, Carroll D. (1880): Report on the Factory System of the United States, U.S. Report of Manufactures of the United States $10^{\text {th }}$ Census, June 1, 1880.

Wright, Gavin (1986): Old South New South, Basic Books, A Division of Harper Collins Publishers.

Zoriada VAZquez, Josefina (1993): «El Federalismo Mexicano, 1823-1847», en Marcello Carmagnani (coord.), Federalismos Latinoamericanos: Méxio/Brasil/Argentina, México, Fondo de Cultura Económica y El Colegio de México. 